\title{
Е.Н Проскурина
}

Институт филологии СО РАН, Новосибирск

\section{Мотивная триада «истина, правда, ложь» в драме М. Горького «На дне»}

Вопрос о правде и лжи в драме Горького «На дне» оформляется в ее центральную философскую проблему только с появлением Луки, по существу с начала второго действия. До этого момента мы наблюдаем вялую перепалку озлобленных друг на друга и на весь мир обитателей ночлежки. Понятия «правда» и «ложь» не выходят здесь за рамки их бытового понимания. Со сцены беседы Луки с умирающей Анной в драму вводится иное, экзистенциальное измерение этих категорий, что в итоге превращает весь текст произведения в спор об истине.

Но вместе с тем возникает и другая сторона вопроса, связанная с пониманием уже образа Луки, самого сложного в драме, до сих пор будоражащего сознание как режиссеров и исполнителей, так и читателей и зрителей. Оказывается, что от отношения к этому герою принципиально зависит трактовка трех центральных понятий всей пьесы: истины, правды и лжи, давая вопросу «что есть истина?» - в его пилатовском понимании - предельно разные разрешения.

Как известно, Горький задумывал Луку отрицательным персонажем и настаивал на таком исполнении и понимании роли: «Лука - жулик. Он, собственно, ни во что не верит. Но он видит, как страдают и мучаются люди. Ему жаль этих людей. Вот он и говорит им разные слова - для утешения...» (Архив А.М. Горького, ОПГ-7-11-1, с. 20 [Горький, 1970, с. 621; далее страницы этого издания приводятся в скобках в тексте работы]); «...Лука? Пройдоха. Жулик ... Обманывает сладкой ложью людей и этим кормится ... С самого начала ... задумал я странника пройдохой, жуликом, да так хорошо вышло у Москвина, что я не стал ему перечить...» (621). В 1912 г., через десять лет после первой постановки драмы, в письме к Львову-Рогачевскому Горький писал: «...убейте одно давнее недоразумение, очень неприятное для меня: развенчайте Луку: это отнюдь не «положительный» характер, это ловко скрытый Маркуша из «Кожемякина», проповедник-нигилист ...» (621).

Странная складывалась ситуация: несмотря на все разъяснения Горького, длившиеся практически на всем протяжении прижизненных постановок драмы, актеры продолжали видеть в Луке положительный персонаж. Более того, сам писатель, объяснявший перед репетицией роль Москвину, первому исполнителю Луки в МХТ, на самой репетиции плакал, захваченный его актерской трактовкой. Но и при чтении пьесы труппе МХТ он тоже не мог удержаться от слез, когда дело доходило до реплик Луки.

«Помню, - рассказывала М.Ф. Андреева, - за большим столом сидели Немирович, Станиславский, Морозов, Алексей Максимыч, Шаляпин, рядом с ним, почти обняв его, Пятницкий. Вся наша труппа. Горький читал великолепно, особенно хорошо Луку. Когда он дошел до сцены смерти Анны, он не выдержал, рас- 
плакался. Оторвался от рукописи, поглядел на всех, вытирает глаза и говорит:

Хорошо, ей-богу, хорошо написал...» (610-611).

В ноябре 1902 г. в Нижнем Новгороде Горький читал еще не напечатанную тогда пьесу. «...помню, как светилось его лицо добротой и лаской, когда он читал, как Лука утешает и успокаивает умирающую женщину» (611), - вспоминала В.А. Виноградова. Чтение пьесы в том же году в Москве зафиксировано в воспоминаниях писателя Н.Д. Телешова: «Первое чтение ... происходило у нас на «Среде» ... Читал сам Алексей Максимович. Читал очень хорошо и увлекательно для слушателей, особенно роль старика Луки. Читая, он сам увлекался...» (611).

Похоже, что, вопреки замыслу, отношение автора к собственному персонажу окончательно определилось все-таки не сразу, но корректировалось под влиянием времени и отношения демократически настроенной критики. Вот как, в частности, отозвался о Луке в рецензии 1903 г. писатель и литературный критик А.В. Амфитеатров: «...более язвительной сатиры на «ложь с благонамеренной целью», чем роль Луки, нельзя написать. И если так вышло у Горького непреднамеренно, невзначай, - тем оно лучше» (617) (курсив мой - Е.П.) ${ }^{1}$. Из сферы поиска смысла бытия, что отмечали первые рецензии на спектакль в качестве главной проблемы драмы и на что указывал, например, Л. Андреев после просмотра постановки в МХТ в 1902 г. («Из романтика ... он словно превратился в философа, настойчиво и мучительно ищущего смысла бытия. Он нагромоздил гору жесточайших страданий, бросил в одну кучу десятки разнохарактерных лиц - и все объединил жгучим стремлением к правде и справедливости» (614)) интерпретационный пафос критики все более сдвигался в сферу обличения христианского сострадания. Это заставило автора объясниться с публикой в известном интервью 1903 г.: «Основной вопрос, который я хотел поставить, это - что лучше: истина или сострадание? Что нужнее? Нужно ли доводить сострадание до того, чтобы пользоваться ложью, как Лука? Это вопрос не субъективный, а общефилософский» (617-618) (курсив мой Е.П.).

Однако на несоответствие между собственным замыслом и его сценическим воплощением Горький обратил внимание еще после первого представления: «...ни публика, ни рецензята - пьесу не раскусили. Хвалить - хвалят, а понимать не хотят. Я теперь соображаю - кто виноват? Талант Москвина-Луки или же неумение автора? И мне - не очень весело» (617). Актуальной же становится эта проблема для Горького в послереволюционное время, когда встал вопрос о включении драмы в репертуар советских театров. Он всерьез задумывается о ее новой редакции, но до дела руки так и не доходят. Хотя им по-прежнему много говорится - в письмах и личных беседах - о проблематике пьесы и в первую очередь, конечно, об авторском смысловом наполнении роли Луки. Со временем в нем растет недовольство собой как автором этого произведения, что главным образом остается связанным с неверной, по его мнению, интерпретацией данного персонажа и отсутствием в пьесе убедительного противостояния философии Луки.

1 Эти подозрения в непреднамеренности имеют под собой определенные основания, которые могут быть обнаружены в переписке Горького. Так, в одном из писем времени создания драмы Горький писал: «Мне хочется солнышка, русского этакого - не очень яркого, но любящего все, все обнимающего» [Горький, 1952, с. 148]. На этот эпистолярный факт указывает в своей книге «Эпическая драма в русской литературе XX века» В.Е. Головчинер [Головчинер, 2001]. В связи с данным обстоятельством исследовательницей предложена этимология имени Луки, в первую очередь связанная с латинским словом lux, что значит свет. То есть Лука в пьесе - прежде всего светоносец. Это заключенное в характере персо нажа светлое начало было сразу же отмечено в христианской среде. «На дне светло, - писал в 1904 г. иеромонах Михаил. - Здесь среди отверженцев, потерявших подобие Божие, в потьмах и грязи минутами совсем хорошо и тепло. Отчего это? - Здесь Лука» [Головчинер, 2001, c. 54]. 
Недовольство собой основывалось у Горького на смутном предчувствии того, что, помимо его воли, в драме оказалась заложена некая смысловая константа, извлечь либо поколебать которую он был не в состоянии, несмотря на годами предпринимаемые усилия. Понимая, что корни собственной неудовлетворенности кроются в его философских посылках, он не видел или не хотел признать их ложной основы. А ведь формулируя главную проблему драмы как вопрос о том, «что лучше: истина или сострадание?» (курсив мой - Е.П.), он именно здесь совершает главную логическую ошибку, жестко противопоставляя эти непротиворечивые понятия. Тем самым уже с самого начала Горьким производится тонкая подмена, ибо под универсальной истиной на самом деле начинает подразумеваться правда новой исторической эпохи.

Здесь, однако, следует сказать несколько слов о границах вводимых понятий. Если истина - это абсолютная категория, обозначающая вечные и неизменные свойства идеального мира, Божественного плана бытия, и антиподом истины является только ложь, а не сострадание, которое может представлять собой один из путей к истине, то правда - категория относительная, о чем свидетельствует глагол править, от которого произошло само данное существительное, ибо править, как известно, можно в разные стороны ${ }^{1}$. Именно поэтому в новейшую эпоху становятся возможны такие понятия, как «комсомольская правда», «ленинская правда», «правда Жириновского» и любого другого партийного лидера, свидетельствующие не о направлении к абсолютному, истинному бытию, а о следовании избранной идеологии некоей группы единомышленников. Примечательно, что заменить в приведенных словосочетаниях правду на истину совершенно невозможно: они тут же теряют смысл, выявляя относительную природу правды. Невозможно, кстати сказать, произвести такую замену и в словах Луки: «Она, правда-то не всегда по недугу человеку ... не всегда правдой душу вылечишь» или «она, правда-то, может, обух для тебя», ибо под правдой в данном случае имеется в виду фактическое положение дел в отношении к каждому персонажу. И такая «правда факта» действительно может стать убийственной для слабой, неподготовленной души. Для того чтобы стало возможным реальное (а не риторическое, как в речах Сатина) преодоление этой правды каждым из героев драмы, Лука и пытается воздействовать на них своим сострадательным участием, причем, отнюдь не ложным и «лукавым» в своей основе, как мы попытаемся показать в дальнейших рассуждениях.

На наш взгляд, сложные взаимоотношения между истиной и правдой и составляют главный философский конфликт пьесы «На дне». Здесь следует сразу оговориться о том, что правда не всегда находится в противоречивых отношениях с истиной. Она может совпадать с нею, в этом случае мы говорим об абсолютной, истинной правде, Божественной правде, либо являться частью истины. В пьесе Горького индикатором степени истинности правды как раз и служит сострадание, а точнее, возможность, допустимость сострадания в границах той или иной правды .

В драме есть несколько персонажей, по отношению к которым Лука, с точки зрения автора и большой части советской критики, выступает как лжец-утешитель. В первую очередь это Анна, Пепел, Настя и Актер. Однако вопрос о том,

\footnotetext{
1 Здесь наша точка зрения расходится с позицией известного и уважаемого исследователя С.Г. Семеновой, сформулированной ею в книге «Тайны Царствия Небесного». Под истиной в данном случае понимается то, «что есть на самом деле», «реальное положение вещей», тогда как правда означает то, что должно быть, «должную истину». Тем самым, на наш взгляд, инверсируется иерархическая система ценностей: истина переводится в разряд категорий относительных, тогда как правда начинает занимать абсолютное положение [Семенова, 1994, с. 111-112].
} 
лжет ли Лука, преподавая уроки жизни каждому из них, до сих пор остается не до конца проясненным и нуждается в дополнительном исследовании ${ }^{1}$. Попробуем вновь обратиться к данной проблеме и для начала еще раз вслушаемся в слова, обращенные Лукой к умирающей Анне:

«Вот, значит, помрешь, и будет тебе спокойно... ничего больше не надо будет, и бояться - нечего! Тишина, спокой... лежи себе! Смерть - она все успокаивает... она для нас ласковая... Помрешь - отдохнешь, говорится... верно это, милая! Потому - где здесь отдохнуть человеку?.. Призовут тебя к господу и скажут: господи, погляди-ка, вот пришла раба твоя, Анна... А господь - взглянет на тебя кротко-ласково и скажет: знаю я Анну эту! Ну, скажет, отведите ее, Анну, в рай! Пусть успокоится... Знаю я, жила она - очень трудно... очень устала... Дайте покой Анне...» (137).

Сказанное Лукой отнюдь не является откровением, в его словах отражены главные чаяния и надежды человека-христианина, в них - все народное православие. Причем, во время создания пьесы это была еще живая народная вера, а не не кий анахронизм, «преданье старины глубокой». Тем более удивляет реакция персонажей на нарисованную Лукой картину, воспринятую ими как сказка или лживая история:

«Медведев (строго). А ты почему знаешь, что там скажут? Эй, ты...» (137);

«Пепел. Тебе, дед, изволь, - уважу! Ты, брат, молодец! Врешь ты хорошо... сказки говоришь приятно! Ври, ничего... мало, брат, приятного на свете!» (138).

Но и для самой Анны речи Луки звучат как услышанная впервые благая весть:

«Анна. Дедушка... милый ты... кабы так! Кабы... покой бы... не чувствовать бы ничего...» (137).

В этом довольно тонко проведенном мотиве ложного первооткровения по отношению к известным и давно адаптированным в сознании русского человека духовным основам жизни видится главный нечестный ход самого автора. Возникающий в сцене мотив сомнения, свидетельствующий о вполне естественном для обыденного человеческого сознания, в том числе и сознания христианского, внутреннем состоянии, ибо путь к спасению, как известно, пролегает между сомнением и надеждой, звучит здесь достаточно робко («Верно... а может, и - не верно!» $(138))$ и тонет в итоге в категоричной отповеди Пепла.

Что же касается последних минут жизни и кончины Анны, то произошедшая в ней, еще совсем недавно жалующейся на жизнь и ропщущей, внутренняя перемена после слов Луки представляет собой чаемый идеал душевного предсмертного состояния человека-христианина, молящего о даровании «кончины мирной, честной и не постыдной». По существу, в эти минуты в ночлежке свершилось никем не замеченное чудо: выправление души человека через примирение с жизнью, приятие собственной судьбы («Коли там муки не будет... здесь можно потерпеть... можно!» (137)), увенчавшееся тихой, спокойной, «непостыдной» смертью, столь нехарактерной для этого «постыдного» места.

Что касается рассказов о Сибири как «золотой стороне», адресованных Пеплу, и совета начать новую жизнь именно в этом краю, то здесь Лука выступает не столько лжецом, сколько провидцем. Причем, о сибирских местах он говорит не как о земле, где «течет мед и молоко», а как о крае, ждущем того, «кто в силе да в

${ }^{1}$ Наиболее обстоятельно рассмотрена данная проблема в книге Г.Д. Гачева [1992]. Однако написанная в 1960-х гг., по меткому замечанию одного из «известных ныне философов» (имя его в книге не названо), с позиции «советского экзистенциализма» [Там же, с. 93], работа, на наш взгляд, существенно перегружена идеологемами - в соответствии с ин версивной логикой, где ключевыми понятиями становятся такие, как «Человекоправда», «Человекомир» и пр. 
разуме». Менее чем через десять лет этой идеей будут захвачены российские переселенцы, инициируемые реформой П. Столыпина. На память приходят и ставшие афористичными слова М. Ломоносова о прирастании российского могущества Сибирью. Но главная истина, заключенная в словах Луки о Сибири, состоит в том, что эта «страна каторги и ссылки» была вместе с тем землей, не знавшей крепостного права, местом свободных землепашцев. Выходит, что и в случае с Пеплом Луку нельзя назвать лжецом. Более того, как и в случае с Анной, своим сострадательным участием он оказывает благотворное влияние на Пепла, который вдруг начинает анализировать и переоценивать прожитые годы:

«...Ты думаешь - моя жизнь не претит мне? Эх, Наташа! Я знаю... вижу!.. Я - не каюсь... в совесть я не верю... Но - я одно чувствую: надо жить... иначе! Лучше надо жить! Надо так жить... чтобы самому себя можно мне было уважать ... Я - сызмальства вор... все всегда говорили мне: вор Васька, воров сын Васька! Ага? Так? Ну - нате! Вот - я вор!.. Ты пойми: я, может быть, со зла вор-то... отто го я вор, что другим именем никто никогда не догадался назвать меня... Назови ты... Наташа, ну?» (158);

«Ты... пожалей меня! Несладко живу... волчья жизнь - мало радует... Как в трясине тону... за что ни схватишься... все - гнилое... все - не держит...» (159).

Насколько непривычно для Пепла раскрывать душу перед другим человеком, свидетельствует обилие пауз, недомолвок в его речи, выраженное в тексте множеством отточий. Словно, исповедуясь перед Наташей и Лукой, он и для себя самого открывает потаенные недра собственной натуры - то, что апостол Петр назвал «сокровенным сердца человеком» $(1$ Петр. 3,4$)$. И мы с удивлением обнаруживаем нетронутую пороком красоту этого внутреннего человека Пепла. Понимая, как трепетно нужно относиться к скрытому от внешнего взора истинному «я» человека, взращивая и укрепляя его через воздействие на сознание, Лука дает совет Наташе:

«Он - парень ничего, хороший! Ты только почаще напоминай ему, что он хороший парень, чтобы он, значит, не забывал про это! Он тебе - поверит... Ты только поговаривая ему: «Вася, мол, ты - хороший человек... не забывай!» ... А парень - крепкий...» (159).

Главные обвинения в адрес Луки в связи с историей Пепла звучат обычно по поводу финального ее разрешения: Пеплу действительно суждено оказаться в Сибири, но не в качестве вольного поселенца, а каторжником. Однако весь вопрос в том, виноват ли в этом Лука. Скорее, виной те обстоятельства, которыми оказался повязан сам Пепел и которые не дали ему возможности реализовать советы Луки, сами по себе вполне осуществимые.

Лука - единственный из обитателей ночлежки, которому дано понять, насколько фактическое положение дел, правда факта, может расходиться с истинной правдой о человеке. Наиболее ярко это противостояние Луки остальным персонажам представлено в сюжетной линии Насти. Романтические мечты этой «девицы легкого поведения» о большой, красивой любви, вычитанной ею из книг, вызывают в ночлежке лишь издевку и смех. Наивысшей степени достигает такая реакция тогда, когда Настя погружается в эти мечты как в реальность и говорит о них как о факте, имевшем место в ее жизни:

«Бубнов. Раскрашивай, ворона, перья... валяй... (хохочет). Ах... чертова кукла! а?» (151-152);

«Барон (тоже смеется). Дедка! Ты думаешь - это правда? Это все из книги «Роковая любовь»... Все это - ерунда! Брось ее... Ну и глупа же эта девица... добрая, но... глупа - нестерпимо!» (152);

«Бубнов. И чего это... человек врать так любит?...» (152).

Совсем по-иному видит ситуацию Лука: 
«Лука. А вы - погоди-ите! Вы - не мешайте! Уважьте человеку... не в слове - дело, а - почему слово говорится? - вот в чем дело! Рассказывай, девушка, ничего! ... Уйдем, милая! Ничего... не сердись! Я-знаю... Я-верю! Твоя правда, а не ихняя... Коли ты веришь, была у тебя настоящая любовь... значит - была она! Была! А на него - не сердись, на сожителя-то... Он... может, и впрямь из зависти смеется... у него, может, вовсе не было настоящего-то... ничего не было! ...» (151-152).

Странным на первый взгляд кажется то обстоятельство, что «настоящим» для Луки является то, чего не было в жизни. Однако этому бродячему философу открыты сущностные основы бытия, он понимает, что не случивщееся в данном случае отнюдь не тождественно несуществующему. Именно мечты Насти представляют собой суть ее натуры, истинное, бытийное ядро ее личности, тот внутренний потенциал души, который не нашел реализации в действительной жизни, в большинстве случаев являющейся неким искаженным, «загрязненным» вариантом Высшего Замысла о человеке, но который актуализирован искренней верой своей собственной и окружающих - в возможность осуществления такой мечты. Как раз на уровне этого Высшего Замысла вполне реальной является утверждение Луки о наличном существовании настоящей любви в судьбе Насти. (Предельно значимым здесь является тождество веры и знания (Лука: «Я - знаю... Я - верю! ... Коли ты веришь, была у тебя настоящая любовь... значит - была она! Была!»)). Жизнь сознания в данном случае оказывается важнее, реальнее, истиннее жизни фактической. Можно говорить об очищающем влиянии мечты на душу героини, приводящей в итоге к осознанию ею того контраста, который существует между желаемым и действительным. То есть посредством мечты происходит пробуждение сознания Насти, вместе с чем растет ее внутренняя убежденность в невозможности, невыносимости дальнейшего пребывания «на дне» жизни.

В качестве наиболее убедительного, на первый взгляд, обвинения Луки во лжи представляется история Актера с ее печальным концом, который обычно трактуется как жест предельного отчаяния. Но попробуем более внимательно всмотреться и в эту историю. Актер - самый интеллигентный из насельников ночлежки. И не столько в силу своей бывшей профессии, но прежде всего потому, что главным вопросом для него является вопрос о смысле жизни. При этом ответ на него герой ищет не в сфере абстрактного гуманизма, как Сатин, но ставит его как проблему личного бытия. Вместе с тем это личное бытие не сужается им до рамок социального положения, его места в обществе, как у Клеща, но представляет собой область духовно-нравственной самоориентации, личной экзистенции. Наиболее явно об этом свидетельствует мотив утраты памяти, возникающий в драме, в первую очередь, в связи с образом Актера ${ }^{1}$ :

«Раньше, когда мой организм не был отравлен алкоголем, у меня, старик, была хорошая память... А теперь вот... кончено, брат! Все кончено для меня! Я всегда читал это стихотворение с большим успехом... Бывало, выйду, встану вот так... Встану... и... (Молчит.) Ничего не помню... ни слова... не помню!...» (135).

Исчезновение памяти является для Актера свидетельством утраты собственного личностного потенциала, погружения в «ничто», из которого он не знает выхода. Это состояние усиливается утратой героем веры в себя, в собственные возможности и силы:

«Таланта нет... нет веры в себя... а без этого... никогда, ничего...» [Там же, c. 134]; «Пропил я душу, старик... я, брат, погиб... А почему - погиб? Веры у меня не было... Кончен я...» (135).

\footnotetext{
${ }^{1}$ Мотив утраты памяти имеет связь и с образом Сатина. Однако, в отличие от Актера, Сатин не воспринимает утрату собственной памяти как личную драму.
} 
По сути дела такое внутреннее самоощущение равнозначно для Актера духовной смерти. В этом отношении совсем не парадоксально звучит его реплика, обращенная к Сатину: «Однажды тебя совсем убьют... до смерти...» [Там же, c. 111]. Не разгадавший смысла произнесенных слов Сатин обзывает Актера болваном, объясняя ему, что «дважды убить нельзя», на что следует многозначительная реплика Актера: «Не понимаю... почему - нельзя?» (111). В отличие от Сатина, Актер разграничивает смерть духа и смерть тела, и духовная смерть является для него гораздо страшнее телесной.

Таким же образом представляется дело и Луке. Именно поэтому он и дает Актеру совет лечиться от пьянства, видя в нем корень всех его нравственных проблем. Однако следующий за этим рассказ о бесплатной лечебнице для алкоголиков как будто бы выводит картину, нарисованную Лукой, за пределы реальности и дает повод для обвинения его в «сострадательной лжи». Но попробуем проследить логическое развитие мысли в речи Луки:

«Лука. Не, чего? Ты... лечись! От пьянства нынче лечат, слышь! Бесплатно, браток, лечат... такая уж лечебница устроена для пьяниц...чтобы, значит, даром их лечить... Признали, видишь, что пьяница - тоже человек... и даже - рады, когда он лечиться желает! Ну-ка, вот, валяй! Иди...

Актер (задумчиво). Куда? Где это?

Лука. А это... в одном городе... как его? Название у него этакое... Да я тебе город назову!.. Tы только вот чего: ты пока готовься! Воздержись!.. возьми себя в руки и - терпи... А потом - вылечишься... и начнешь жить снова... хорошо, брат, снова-то! Ну, решай... в два приема...

Актер (ульгбаясь). Снова... сначала... Это - хорошо... Н-да... Снова? (Смеется). Ну... да! Я могу!? Ведь могу, $а$ ?

Лука. А чего? Человек - все может... Лишь бы захотел...» (136).

Говоря в начале беседы о существовании лечебницы для пьяниц, Лука, однако, простраивает модель дальнейшего поведения Актера таким образом, что главное значение для него начинает иметь не сама лечебница, а неожиданно возникающее радостное чувство веры в себя. Происходит это потому, что в своих убеждениях мудрец Лука основной упор делает не на воздействие лечения, а на воздержание, терпение, готовность «взять себя в руки», то есть на раскрытие внутренних ресурсов личности Актера, на проявление его «сокровенного человека», истинного «я». В таком случае отпадет необходимость в какой-либо лечебнице, кроме той, которая находится в душе человека и представляет собой его внутренний храм в соответствии со словами Христа: «Царствие Божие внутрь вас есть».

Плоды этой возрожденной Лукой веры Актера в себя дают о себе знать очень скоро, настолько скоро, что он не успевает осознать происшедшей в нем перемены и словно оглушен ею:

«Актер (останавливается, не затворяя двери, на пороге и, придерживаясь руками за косяки, кричит). Старик, эй! Ты где? Я - вспомнил... слушай. (Шатаясь, делает два шага вперед и, принимая позу, читает.) [Далее следует чтение Актером стихов Беранже]

Наташа (смеется). Чучело! Нализался...» (146).

Однако, пожалуй, впервые за все время пьянство Актера является здесь свидетельством радости, а не отчаяния, внутреннего пробуждения, а не сна, за чем следует его готовность оставить ночлежку и идти искать вожделенную лечебницу. Для этого он начинает копить деньги и действительно перестает пить.

«Актер. ... Я - иду! Я сегодня - работал, мел улицу... а водки - не пил! Каково? Вот они - два пятиалтынных, а я - трезв!» (163).

Пьяным мы больше не увидим героя, вплоть до момента его ухода, но и в этой последней сцене Актер пьет, скорее, «для храбрости», чем из желания пить: 
«Актер (быстро слезает с печи, подходит к столу, дрожащей рукой наливает водки, пьет $u$ - почти бежит - в сени)», предваряя свой последний жест обращением к Татарину: «Помолись... за меня!» (178).

В этой последней сцене с участием Актера важно все: и его просьба о молитве, впервые звучащая из его уст, и торопливость жестов, движений, как будто он боится промедления, и его последнее решительное «Ушел!». Попытаемся же понять, что послужило поводом такого разрешения судьбы героя. На первый взгляд кажется, что всему виной действительно Лука, обольстивший Актера красивой сказкой и исчезнувший в самый критический момент. Обратим, однако, внимание на беседу Сатина с Лукой - в желании первого открыть глаза Актеру на обман старика:

«Сатин. Чепуха! Никуда ты не пойдешь... все это чертовщина! Старик! Чего ты надул в уши этому огарку?..

Лука (Сатину). А ты - почто его с толку сбиваешь?» (163).

Здесь сталкиваются две позиции по отношению к конкретному человеку, его дальнейшей судьбе. Позиция Сатина предстает позицией равнодушного материалиста, в сознании которого правда не выходит за пределы земной реальности, накрепко с ней слита здесь и сейчас. И человек должен быть всегда готов воспринять эту правду во всей ее наготе.

Для Луки же земная правда - это лишь правда данного момента, человек же - больше этого момента, а значит и больше такой правды. Жизнь человека это путь к самому себе, своему высшему, истинному «я». Нужно лишь встать на него и найти в себе силы не свернуть с него и не отказаться от него. Потому-то, по логике Луки, так важно для Актера, с его неокрепшим сознанием, находящегося лишь в начале этого пути, не быть «сбитым с толку». Дальше же, когда душа его окрепнет и овладеет внутренним зрением, ему будет уже по силам осознать истинный смысл слов Луки. И такое своевременное осознание должно лишь укрепить веру человека в свои внутренние силы, а не подорвать либо поколебать ее.

Итог жизни «сбитого с толку» правдой Сатина Актера, казалось бы, повторяет судьбу героя притчи «о праведной земле». Однако внешнее соответствие в данном случае отнюдь не означает внутреннего смыслового тождества. Герой притчи, искавший «праведную землю» и вдруг узнавший от ученого человека, что такой земли нигде в его книгах и планах нет, озлобился, избил своего «просветителя», «а после того пошел домой и - удавился» (157). Актер, «просвещенный» скептиком Сатиным, тоже начал осознавать, что лечебница для алкоголиков - плод воображения Луки. Но именно поспешность «правдолюбца» Сатина, а не кажущиеся ложью слова Луки, сыграла злую шутку с Актером, ибо не дала возможности, а главное, времени для того, чтобы в сознании Актера сформировалась, «проросла» мысль о том, что «праведная земля» - это то Царство, которое «не от мира сего» и которое всегда есть, пусть образ его и прочно забыт обитателями ночлежки.

Однако есть еще одно принципиальное отличие между героем притчи и Актером. Первый уходит из жизни озлобившимся и отчаявшимся. Уход Актера ничего подобного под собой не имеет. За этим финальным жестом персонажа стоит целая культурная традиция, которая актуализируется им вполне осознанно. Иными словами, Актер вполне «ведает, что творит». Вот одна из последних сцен с его участием, где имя Актера возникает в связи с желанием Насти оставить ночлежку:

«Сатин. Пойдешь, - так захвати с собой Актера... Он туда же собирается... ему известно стало, что всего в полуверсте от края света стоит лечебница для органонов...

Актер. Да! Он - уйдет! Он уйдет... увидите!

Барон. Кто - он, сэр?

Актер. Я! 
Барон. Mersi, служитель богини... как еe? Богиня драм, трагедии... как еe звали?

Актер. Муза, болван! Не богиня, а - муза!

Сатин. Лахеза... Гера... Афродита... Атропа... черт их разберет! Это все старик... навинтил Актера...

Актер. Невежды! Дикари! Мель-по-ме-на! Люди без сердия! Bы увидите он уйдет! «Обжирайтесь, мрачные умы»... стихотворение Беранжера... да! Он найдет себе место... где нет... нет...

Барон. Ничего нет, сэр?

Актер. Да! Ничего! «Яма эта будет мне могилой... умираю, немощный и хильй!» Зачем вы живете? Зачем?» (172).

Из этой сцены видно, что желание Актера уйти из жизни не является стихийным, спонтанным, но представляет собой итог его внутренней рефлексии. Своим пробужденным сознанием он вдруг увидел себя служителем Мельпомены, то есть трагедийным актером, и в своих последних репликах пытается соответствовать этому сценическому амплуа, по существу исполняя свою последнюю роль (знаковым является и факт возрождения памятью театрального имени Актера: Сверчков-Заволжский). На это указывает переход на высокий стиль, беседа героя о самом себе в третьем лице («Вы увидите - он уйдет...»). В жестких характеристиках («невежды», «дикари», «люди без сердца»), в существе тех вопросов, с которыми Актер обращается к своим собеседникам («Зачем вы живете?») видится захваченность героя просветительским пафосом, желание пробудить спящее сознание своих товарищей по несчастью. Делая вызов окружающей жизни, осознавая невозможность жить по-прежнему и не представляя при этом, как ему жить дальше, Актер, однако, знает, как может быть прекращена такая жизнь. Его актерский опыт предоставлял здесь множество моделей. И он решает доиграть свою роль до конца, делая личный выбор в представшем перед ним «гамлетовском вопросе». Таким образом, уход из жизни Актера есть не жест крайнего отчаяния, а плод свободного экзистенциального выбора, его способ вырваться из безбытного, инверсированного пространства «дна». В то же время попытка пробуждения сознания окружающих его людей через уход из жизни придает смерти Актера жертвенный смысл - в русле античной традиции. Трагедийное начало этого артефакта усиливается последней репликой Сатина: «Эх... испортил песню... дурак!», наделяющей уход Актера смысловыми коннотациями «напрасной жертвы», а на саму атмосферу «дна» накладывающей отпечаток безвыходного, смертельного равнодушия. Отсутствие Луки делает это состояние удушливости предельно ощутимым.

Можно сказать, что сострадательное участие Луки явилось для участников драмы той самой евангельской «закваской», которая, прорывая покровы их душ, открывает каждому его личный путь к своему сокровенному «я». Как замечает проницательный Сатин, старик действительно «проквасил сожителей». Внезапное же исчезновение Луки делает героев оставленными на произвол судьбы. Их пробужденное сознание оказывается в то же время не готовым еще противостоять жестокой правде факта. «Поманил их куда-то... а сам - дорогу не указал...» (172), сокрушается по этому поводу Клещ.

Однако исчезновение Луки в конце третьего акта вряд ли является свидетельством «лукавства», лживости его натуры, на что пытается указать автор через реплики персонажей, представляющие собой искаженный текст защитной молитвы («Исчез от полиции... яко дым от лица огня»; «Тако исчезают грешники от лица праведных!»). Исчезновение Луки - всего лишь вынужденный поступок беспаспортного бродяги, не желающего иметь дело с полицией, а не уход от ответствен ности перед обитателями ночлежки. По отношению к ним он ни разу не проявил себя «пройдохой» и «жуликом», действующим из выгоды, как мыслил и говорил о 
сути характера Луки Горький. И на трагический финал Актера больше повлияло, думается, именно отсутствие Луки, чем адресованные ему Лукой рецепты исцеления. Будь старик в это время среди ночлежников, вероятнее всего, что Актер остался бы жив.

И тем не менее на протяжении всего четвертого акта драмы постоянно ощущается косвенное присутствие Луки. Разговоры в ночлежке ведутся большей частью вокруг его имени, а суть этих разговоров также свидетельствует о благотворном воздействии старика на персонажей. Даже Клещ после исчезновения Луки смягчает свою гордую неприступность: приобщается к общей жизни, начинает помогать другим (чинит Алешке гармонь), размышлять о правде, о должной жизни, о человеке:

«Надо жить - по закону... по Евангелию...» (171);

«Ничего... Везде - люди... Сначала - не видишь этого... потом - поглядишь, окажется, все люди... ничего!» (176).

В этих словах он по существу повторяет мысли Луки, не раз высказанные тем в ночлежке. Здесь нельзя обойти вниманием авторские ремарки к первому и четвертому актам пьесы, в связи со сказанным приобретающие неожиданные смысловые обертоны. Если в первом акте свет в ночлежку проникает извне- от зрителя - и сверху - через окно (ср. с явлением Луки-светоносца), то в четвертом акте на дворе ночь, и комната ночлежников освещается только лампой изнутри. Таким образом, вновь вопреки собственному замыслу, автор оставляет в тексте пометы, становящиеся знаковыми маркерами благотворного воздействия Луки на персонажей, ибо не что иное, как возгорание внутреннего духовного света означает в данном случае горящая в ночной комнате лампа. Наличие этой художественной детали дает повод для переакцентировки внимания с внешнего плана действия на внутренний, несмотря на то и даже вопреки тому, что для самого Горького главным в сценическом оформлении пьесы было актуализировать ощущение сгущающейся до кромешной ночи тьмы.

Ближе всех к пониманию философии Луки стоит Сатин. Однако для него она является не столько точкой притяжения, сколько отталкивания. Начиная свою речь с защиты старика, он в дальнейшем выстраивает противоположную его отношению к жизни и человеку концепцию, в которой не находится места личностному началу, хотя видимым центром его философии также является человек.

Сатин входит в триаду персонажей (+ Барон и Бубнов), на которых явление Луки не оказало явного возрождающего воздействия. Если знаком внутренней опустошенности Барона на протяжении всего действия пьесы являются его циничные замечания, для Бубнова тем же маркирующим смыслом наделены его афористичные суждения, представляющие собой форму застывшей мысли, штампа, оправдывающего его инертное отношение к происходящему («Шум - смерти не помеха»), то финальная речь Сатина о человеке - это апофеоз позиции отчуждения, заявленной персонажем еще в начале пьесы. Эта речь подготовлена его положением человека, выпавшего в инакомирие «дна», принявшего его и практически отождествившегося с ним, не только утратившего цель жизни, но отказавшегося от каких бы то ни было способов участия в ней. Поэтому главное в речи Сатина это не вопрос, а ответ, который уже готов в его сознании и служит оправданием собственной пассивности, отъединенности от мира:

«Хорошо это... чувствовать себя человеком!.. Я - арестант, убийца, шулер... ну, да! Когда я иду по улице, люди смотрят на меня, как на жулика... и сторонятся, и оглядываются... и часто говорят мне - «Мерзавец! Шарлатан! Работай!» Работать? Для чего? Чтобы быть сытым? (хохочет). Я всегда презирал людей, которые слишком заботятся о том, чтобы быть сытыми... Не в этом дело, Барон! Не в этом дело! Человек - выше! Человек - выше сытости!.. 
Барон (качая головой). Ты рассуждаешь... Это хорошо... это, должно быть, греет сердце... У меня - нет этого... я - не умею! ... Я, брат, боюсь... иногда. Понимаешь? Трушу... Потому - что же дальще?

Сатин (ходит). Пустяки! Кого бояться человеку? ...» (177).

Такая предельно абстрагированная, отчужденная от конкретного человека $n р а в д а$, выведенная из позиции «всеясности» («Пустяки! Кого бояться человеку!») действительно не предполагает вопроса, рефлексии, и уже в силу этого есть инверсированное представление о человеке, его месте в мироздании, его телеологии:

«...Это - огромно! В этом - все начала и концы... Все - в человеке, все для человека! Существует только человек, все же остальное - дело его рук и его мозга!...» (177).

В лоне такого абстрактного гуманизма нет и не может быть места сострадательному отношению к человеку, ибо главным лейтмотивом данной концепции становится формула «Человек - это звучит гордо!». В таком случае, как верно отмечает Г. Гачев в книге «Логика вещей и человек. Прения о правде и лжи в пьесе М. Горького «На дне»», «мысль о Человеке не есть суждение; она - лишь внешне походит на его форму» [Гачев, 1992, с. 76]. Речь Сатина отличается предельной афористичностью и эмоциональным пафосом, что представляет собой наилучшую риторическую возможность преодоления логических провалов, ибо главная установка такого способа высказывания - это ориентация на волю и действие, а не на философскую рефлексию. «Монологи Сатина, - читаем в указанной работе Г. Гачева, - это стремление логики превзойти свои границы и выйти сразу в мир действия. Это своего рода заклинания, магические действия со словами. Сатин, который в первом акте вяло соединял опостылевшие слова - через многоточия, здесь соединяет их волевым напором: посредством тире перебрасывая мосты через еще не освоенные мыслью бездны и пустоты» (выделено автором - Е.П.) [Там же, с. 76].

Самым же главным в данном случае является то, что, произнося свою пафосную речь о человеческом самовластии, Сатин вряд ли понимает, что такая установка чревата глубинными мутационными изменениями, результатом которых может стать абсолютная инверсия сознания, представляющая собой полярную перемену всей системы ценностей, что и произошло в исторической реальности России через пятнадцать лет после выхода пьесы Горького. «В универсуме библейско-христианской культуры ... (а именно с этой традицией имеет в данном случае дело Горький - Е.П.) первоисточная, архетипальная инверсия ... - низвержение Сатаны с небес в преисподнюю, - пишет в одной из своих работ С. Хоружий, - ... сам же Сатана, Денница, Люцифер, «спадший с неба как молния» (Лк. 10, 18), есть демон инверсии и даже ее демиург, поскольку у него имеется некое свое царство, в котором инверсия, инвертированность (перевернутость) - универсальный и обязательный закон» [Хоружий, 1995, с. 22]. В этом отношении поистине знаковым становится само имя Сатина, от которого выстраивается вполне определенная смысловая цепочка: Сатин - Сатан - Сатана. В таком случае и проповедуемая героем правда о человеке прочитывается в соответствии с семантикой имени дьявола как «лжеца» и «человекоубийцы» $($ Ин. 8,44$)$ и представляет собой ложную правду, то есть направленную не к истине, а от истины ${ }^{1}$.

Подводя итог нашим размышлениям, следует указать на ту существенную разницу, которая обнаруживается между замыслом Горького произвести ревизию традиционной ценностной системы и утвердить в качестве новой позитивной мировоззренческой тенденции философию Сатина и художественным осуще-

${ }^{1}$ «Чертовской» назвал мировоззренческую тенденцию Горького художник М.В. Нестеров в одном из своих писем, где идет речь о постановке пьесы «На дне» 1903 г. См.: [Горький, 1970, с. 617]. 
ствлением этого замысла. Текст пьесы «На дне» дает основания утверждать, что творческая интуиция автора оказалась здесь гораздо тоньше по сравнению с рациональной установкой писателя. И это еще одно весомое художественное доказательство тезиса о непоругаемости Истины.

\section{Литература}

Гачев Г.Д. Логика вещей и человек. Прение о правде и лжи в пьесе М. Горького «На дне». М., 1992.

Головчинер В.Е. Эпическая драма в русской литературе XX века. Томск, 2001.

Горький М. Собрание сочинений: В 30 т. М., 1952. Т. 28.

Горький М. Полное собрание сочинений: В 25 т. Т.7. М., 1970.

Семенова С.Г. Тайны Царствия Небесного. М., 1994.

Хоружий С. Бахтин. Джойс. Люцифер // Бахтинология. СПб., 1995. 